\title{
ECO-LITERACY FIQH ALABî'AH DALAM HUKUM NASIONAL
}

\author{
\begin{tabular}{r|l} 
Moh. Mufid & Univeritas Islam Negeri Sunan \\
moephid@yahoo.com & Ampel Jl. A. Ayni 117 Surabaya
\end{tabular}
}

\begin{abstract}
The environmental crisis is a contemporary issue that draws the public attention. In Islam, protecting environment is an important aspect in preserving the existence of the macro life for all God's creatures without dwarfing one another. That is why in the environmental Islamic jurisprudence, protecting environment (hifz al-bî'ah) is equal as keeping religion (hifz al-dîn), protecting soul (hifz al-nafs), maintaining intellect (hifz al-aql), maintaining descent (hifz al-nasl), and maintaining property (hifz almâl). The reason is that if the aspects of religion, life, intellect, lineage and property damaged, then the existence of humans on the environment becomes stained. Thus, al-Qaradawi made hifz al-bî́ah as an Islamic axiological study. From here, the effort to develop the epistemological basis of Islamic environmental jurisprudence becomes a necessity. Therefore, in this context, maqâshid al-syarî'ah (hifz al-bî'ah) is the main purpose of Islamic law. It can also be an "approach" in reformulating the "anthropological and cosmological-based Islamic environmental jurisprudence".
\end{abstract}

Keywords: Fiqh al-bî̃ah, hifz al-bîah, eco-literacy, national law.

Abstrak: Krisis lingkungan merupakan isu kontemporer yang menyita perhatian publik. Dalam Islam, menjaga lingkungan merupakan aspek penting dalam upaya melestarikan eksistensi kehidupan makro bagi seluruh makhluk ciptaan Tuhan tanpa mengerdilkan satu sama lain. Itu sebabnya, doktrin Islam tentang fikih ramah lingkungan menyatakan bahwa menjaga lingkungan (hifz al-bîah) sama dengan menjaga agama (dîn), jiwa (nafs), akal (aql), keturunan (nasl), dan harta (mâl). Rasionalitasnya adalah bahwa jika aspek-aspek agama, jiwa, akal, keturunan dan harta rusak, maka eksistensi manusia di dalam lingkungan menjadi ternoda. Dengan demikian, al-Qardâwî menjadikan hifz al-bî’ah sebagai kajian aksiologi ilmu-ilmu keislaman. Dari sini, maka upaya pengembangan basis epistemology fikih lingkungan menjadi suatu keniscayaan. Maqâshid syarî'ah (hifz al-bî̀ah) sebagai tujuan utama agama dapat menjadi "pisau analisis" dalam mereformulasikan fikih lingkungan yang berbasis antropokosmis.

Kata Kunci: Fiqh al-bĩah, hifz al-bîah, eco-literacy, hukum nasional. 


\section{Pendahuluan}

Dewasa ini, krisis lingkungan sudah menjadi isu global dan menjadi concern hampir semua lapisan masyarakat dunia. Problem pencemaran lingkungan banyak mendapat sorotan dari pelbagai kalangan termasuk dari kalangan agamawan. Menurut Graham Parkes dari Universitas Hawai yang menekuni peran agama dalam mengatasi beberapa krisis budaya, yakni hubungan kebudayaan manusia dengan alam lingkungan, dalam teorinya menunjukkan bahwa pandangan keagamaan suatu kelompok masyarakat sangat berpengaruh dalam menentukan sikap dan perilaku terhadap alam dan lingkungannya. ${ }^{1}$

Manusia dan alam dalam perspektif Islam memiliki hubungan yang sangat erat. Tuhan menciptakan alam ini, termasuk di dalamnya manusia memiliki keteraturan, keseimbangan dan keserasian yang dalam bahasa agama disebut sunnatullâh. Keberlangsungan hidup makhluk di dalamnya sangat dipengaruhi oleh gejala-gejala lingkungan yang mengitarinya. Oleh karena itu, keseimbangan dan keteraturan alam ini harus terus dipelihara agar tidak terjadi kerusakan di dalamnya.

Laporan Intergovermental Panel on Climate Change (IPCC) tahun 2001 tentang penyebab global warming menunjukkan bahwa $66 \%$ manusia adalah penyebabnya. Pada tahun 2007, laporan yang sama menunjukkan prosentasi meningkat menjadi $90 \%$. Bertolak pada data ini, para ilmuwan menyimpulkan dan menyakini dominasi manusia

\footnotetext{
1 Lihat Alwi Shihab, Islam Inklusif Menuju Sikap Terbuka dalam Beragama (Bandung: Mizan, 2009), 65. Agama, sebagaimana dikemukakan oleh Mary Evelyn Tucker (2003) mempunyai lima resep dasar untuk menyelamatkan alam dan lingkungan; (1) Reference atau keyakinan yang dapat diperoleh dari teks (kitab-kitab suci) dan kepercayaan yang mereka miliki masing-masing; (2) Respect, penghargaan kepada semua makhluk hidup yang diajarkan oleh agama sebagai makhluk Tuhan; (3) Restrain, kemampuan untuk mengelola dan mengontrol sesuatu supaya penggunaanya tidak mubazir; (4) Redistribution, kemampuan untuk menyebarkan kekayaan; kegembiraan dan kebersamaan melalui langkah dermawan; misalnya zakat, infak dalam Islam; (5) Responsibility, sikap bertanggung jawab dalam merawat kondisi alam dan lingkungan. Dalam hal ini, kepedulian terhadap alam dan lingkungan amat tergantung pada bagaimana aspek-aspek ajaran agama disajikan dan dieksplorasi dengan bahasa serta idiom-idiom modern dan ekologis.

${ }^{2}$ Menurut para ahli, global warming menyebabkan banyak bencana: banjir, angin topan, musim kemarau panjang, evaporasi air tawar, meluasnya kebakaran hutan, meledaknya penyakit hewan dan tanaman baru, dan bencana-bencana lain. Hal yang paling nyata dari ancaman global warming, yaitu naiknya permukaan laut. Lihat Rachmad K. Dwi Susilo, Sosiologi Lingkungan dan Sumber Daya Alam; Perspektif Teori \& Isu-Isu Mutakhir(Yogyakarta: Ar-Ruzz Media, 2012), 69.
} 
sebagai penyebab utama bencana krisis lingkungan di bumi tidak bisa dielakkan. ${ }^{3}$

Upaya untuk mengatasi krisis lingkungan yang kini sedang melanda dunia bukanlah hanya persoalan teknis, ekonomis, politis, normatif, dan sosiologis secara parsial. Akan tetapi, diperlukan upaya penyelesaian dari berbagai perspektif secara komprehensif, termasuk salah satunya adalah melalui perspektif fikih. Karena fikih pada dasarnya merupakan "jembatan penghubung" antara etika (perilaku manusia) dan norma-norma hukum untuk keselamatan alam semesta (kosmos) ini. ${ }^{4}$ Dikatakan sebagai panduan etis, karena fikih mempunyai latar belakang konsideran normatif (deduksi) atau maslahah-mafsadah (induksi). Dikatakan sebagai peraturan normatif, karena memiliki wadah hukum yang berwujud taklîfi, yaitu al-wujûb, al-mandûb, al-mubâh, al-karâhah dan al-hurmah. ${ }^{5}$

Dalam merespons krisis lingkungan ini meniscayakan rumusan fikih ekologi yang juga harus didukung dengan kerangka epistemologi yang kuat secara filosofis. Karena tanpa metodologi ijtihad fikih lingkungan yang memadai, niscaya pengembangan fikih ramah lingkungan hanya akan menjadi wacana belaka. Dengan demikian, upaya mengatasi krisis lingkungan melalui perspektif fikih, maka juga menjadi keniscayaan untuk merekonstruksi kerangka epistemologinya secara sistematis dan dapat dipertanggung jawabkan secara ilmiah.

Dalam konteks keindonesian, fikih lingkungan saja tidak cukup. Oleh karena itu, upaya positivisasi fikih lingkungan menjadi agenda politis yang niscaya diperjuangkan. Hingga saat ini, sudah banyak Undang-Undang yang bernuansa ekologis telah diterbitkan. Misalnya, UU No. 5 tahun 1990 tentang Konservasi Sumber Daya Alam Hayati dan Ekosistemnya, UU. No. 27 tahun 2007 yang telah diubah dengan

\footnotetext{
${ }^{3}$ Kondisi di atas, menjadi sebab kekhawatiran Sir Nicholas Stern atas masa depan iklim bumi. la mengingatkan apabila sikap manusia dalam memengaruhi bumi masih seperti sekarang dan tren konsumsi energi dan penggunaan bahan bakar, perubahan fungsi lahan, pengundulan hutan serta industri tidak berubah, dalam jangka tahun 2010 sampai dengan 93 tahun mendatang akan terjadi kenaikan suhu bumi, yang mengakibatkan kenaikan permukaan air laut. Lihat Fachruddin $M$. Mangunjaya, Bertahan di Bumi; Gaya Hidup Menghadapi Perubahan Iklim (Jakarta: yayasan Obor Indonesia, 2008), 2.

${ }^{4}$ Ahmad Syafi'i SJ., "Fiqih Lingkungan: Revitalisasi Ushul al-Figh untuk Konservasi dan Restorasi Kosmos", Paper disampaikan pada 9th Annual Conference of Islamic Studies, Surakarta 2-5 November 2009.

${ }^{5}$ Sukarni, Fikih Lingkungan Hidup (Banjarmasin: Antasari Press, 2011), 45.
} 
UU No. 1 tahun 2014 tentang Pengelolaan Wilayah Pesisir dan PulauPulau Kecil, UU No. 32 tahun 2009 tentang Perlindungan dan Pengelolaan Hidup dan sebagainya.

Berangkat dari sini, dalam rangka mengatasi krisis lingkungan dibutuhkan rumusan fikih lingkungan kontemporer. Dari rumusan itulah nantinya dilakukan positivisasi terhadap fikih lingkungan sebagai landasan perumusan hukum nasional. Oleh karena itu, makalah ini difokuskan pada pembahasan seputar urgensi dan konsep fikih lingkungan, kerangka epistemologis fikih lingkungan dan politik fikih lingkungan.

\section{Urgensi, Prinsip dan Konstruk Fiqh Lingkungan}

Fikih lingkungan termasuk salah satu bahasan fikih kontemporer (fiqh al-mu'âshir). Term fikih lingkungan di Indonesia baru digagas oleh para cendikiawan Muslim seperti KH. Ali Yafie melalui karyanya "Merintis Fiqh Lingkungan Hidup", Mujiyono Abdillah dalam karyanya "Konseptualisasi Fikih Lingkungan," A. Qadir Gassing "Fikih Lingkungan: Telaah Kritis tentang Penerapan Hukum Taklifi dalam Pengelolaan Lingkungan Hidup", Sukarni dalam karyanya "Fikih Lingkungan Hidup" dan lainnya.

Term fikih, dalam bahasa Arab diartikan sebagai pemahaman. ${ }^{6}$ Secara terminologi, fikih merupakan sekumpulan hukum syar'i yang berkaitan dengan perbuatan yang diambil dari dalil-dalil yang spesifik.? Dengan demikian, gagasan fikih lingkungan ini dapat dipahami sebagai seperangkat aturan tentang perilaku ekologis manusia yang ditetapkan oleh ulama berkompenten berdasarkan dalil yang terperinci untuk tujuan kemaslahatan kehidupan yang bernuansa ekologis. ${ }^{8}$

\footnotetext{
${ }^{6}$ Dalam sejarahnya, istilah figh mengalami perkembangan dalam tiga fase: pertama, istilah figh berarti fahamidentik dengan ra'y sebagai kebalikan 'ilm yang identik dengan riwayah. Kedua, figh yang mengacu pada pengetahuan tentang agama secara umum. Ketiga, figh berarti suatu jenis disiplin dari jenis-jenis penegtahuan Islam atau ilmu-ilmu keislaman. Lebih lanjut, Azizy mengemukakan, bahwa figh lebih tepat disebut sebagai ilmu hukum Islam untuk dipadankan dengan pengertian ilmu hukum seperti pada umumnya. Alasannya, bahwa fikih dalam tahap atau lingkup ilmu hukum, yang kemudian dapat dijadikan atau diputuskan sebagai hukum positif, baik melalui undang-undangmaupun melalui keputusan hakim (yurisprudensi), termasuk melalui fatwa dalam tradisi hukum Islam. Lihat, A. Qodri Azizy, Elektisisme Hukum Nasional: Kompetisi Antara Hukum Islam dan Hukum Umum (Yogyakarta: Gama Media, t.th), 2-4.

${ }^{7}$ Abd Wahhab Khallaf, 'Ilm Ushûl al-Figh (Kuwait: Dar al-Qalam, 1978), 11.

${ }^{8}$ Dari uraian di atas, minimal ada empat hal yang perlu digarisbawahi secara opeasionalnya: pertama, seperangkat aturan perilaku yang bermakna bahwa aturan-aturan yang dirumuskan
} 
Sebagai disiplin ilmu yang mengatur hubungan manusia dengan Tuhannya, hubungan manusia terhadap dirinya sendiri, hubungan manusia terhadap sesama manusia, hubungan manusia terhadap lingkungan hidup di sekitarnya, maka tidak diragukan bila fikih memiliki peran yang sangat krusial dalam merumuskan tata kelola lingkungan hidup yang sesuai dengan hukum-hukum syara', sebagai panduan dalam berinteraksi dengan alam sekitarnya.

Terkait urgensi fikih lingkungan di era kontemporer, minimal ada empat argumentasi yang mendukungnya, yaitu: Pertama, realitas atas terjadinya krisis lingkungan yang semakin parah baik di negara-negara Muslim maupun negara global lainnya. Hal ini memerlukan partisipasi dari ajaran Islam sebagai agama rahmat lil âlamîn. Salah satu partisipasi ini diwujudkan dalam rumusan fikih lingkungan (fiqh al-bî̀ah). ${ }^{10}$

Kedua, umat Islam memerlukan kerangka pedoman komprehensif tentang pandangan dan langkah-langkah partisipatif di dalam masalah konservasi lingkungan. Fikih klasik dipandang tidak memadai lagi dan belum mengakomodir dalam bentuk operasional panduan terkait upaya

mengatur hubungan prilaku manusia dalam interaksinya dengan alam. Rumusan aturan perilaku tersebut akan diwadahi dengan hukum-hukum fikih dalam lima wadah: al-wujuûb, an-nadb, alibâhah, al-karâhah, dan al-hurmah. Dengan demikian, seperangkat interaksi tersebut mengacu pada status hukum perbuatan mukallaf dalam interaksinya dengan lingkungan hidup. Kedua, maksud dari kalimat "yang ditetapkan oleh ulama yang berkompeten" adalah bahwa, perumusan fikih lingkungan harus dilakukan oleh ulama yang mengerti tentang lingkungan hidup dan menguasai sumber-sumber normatif (al-Qur'an, hadis, dan ijtihad-ijtihad ulama) tentang aturan fikih lingkungan. Dengan demikian, mujtahid lingkungan mesti memiliki pengetahuan ideal normatif dan pengetahuan tentang fakta-fakta empirik lingkungan hidup. Oleh karena itu, perumusan fikih lingkungan mesti melibatkan pengetahuan tentang ekologi. Ketiga, yang dimaksud dengan "berdasarkan dalil yang terperinci" adalah bahwa penetapan hukum fikih lingkungan harus mengacu kepada dalil. Dalil, dalam hal ini, tidak hanya dipahami secara tekstual dalam arti nas yang sarih, tetapi mencakup dalil yang diekstrak atau digeneralisir dari maksud syariat. Keempat, maksud dari kalimat " untuk tujuan mencapai kemaslahatan kahidupan yang bernuansa ekologis" adalah sesuatu yang ingin dituju oleh fikih lingkungan, yaitu kehidupan semua makhluk Tuhan. Hal ini menggambarkan aksiologi fikih lingkungan yang akan mengatur agar semua sepesies makhluk Tuhan dapat hidup dalam space alam yang wajar sehingga akan memberikan daya dukung optimum bagi kehidupan bersama yang berprikemakhlukan, rahmatan li al'âlamîn. Lihat Mujiono Abdillah, Fikih Lingkungan (Yogyakarta: Unit Penerbitan dan Percetakan YKPN, 2005), 55-57; Sukarni, Fikih Lingkungan Hidup, 9.

${ }^{9}$ Ridwan Tahopi, Konservasi Pesisir dalam Perspektif Studi Islam (Yogyakarta: Pustaka Pelajar, 2014), 215.

${ }^{10}$ Konsep ini sebenarnya telah dikonstruk oleh para ulama dan intelektual Muslim yang sejatinya terus perlu dielaborasi ke dalam konsep-konsep yang lebih operasional dan melalui pelembagaan formal. Perpaduan antar nilai ajaran Islam dengan kearifan lokal sosial budaya, termasuk kearifan lokal dalam mengelola lingkungan dan hukum tentunya akan saling menguatkan. Dalam konteks umat Islam, hal ini akan memperkuat aspek jiwa dari sebuah hukum formal. 
konservasi lingkungan dalam perspektif dan wawasan krisis lingkungan modern.

Ketiga, fikih lingkungan belum dianggap sebagai disiplin yang masuk ke ranah studi Islam. Akar-akar ontologis dan epistemologisnya masih diperdebatkan sehingga dianggap sebagai bagian dari ilmu lingkungan. Memang, di dalam fikih muamalah terdapat tema-tema seperti ihyâ al-mawât, himâ, al-harîm dan sebagainya, namun itu masih bersifat generik dan etis. Hal ini tentunya diperlukan penjelasan yang lebih operasional, kontekstual dan berbobot ekologis.

Keempat, fikih lingkungan sebagai induk konservasi lingkungan berbasis ajaran Islam perlu dimasukkan ke dalam program-program pendidikan. Hal ini sangat penting karena kesadaran mengenai konservasi lingkungan sangat efektif melalui strategi pendidikan dan kebudayaan. Dengan demikian, pengembangan fikih lingkungan memperoleh perhatian serius dari berbagai pihak. ${ }^{11}$

Konsep fikih lingkungan sebenarnya telah digagas embrionya oleh para fuqaha klasik. Fikih yang bernuansa ekologis ini dapat ditemukan dalam literatur klasik. Meskipun tidak secara eksplisit konsep itu disinggung dalam turats fikih klasik. Misalnya, kitab al-Mughnî karya Ibn Qudamah yang membahas konservasi sungai. Menurut Ibn Qudamah salah satu ulama mazhab Hanbali mengemukakan bahwa setiap sungai harus memiliki zona bebas untuk kepentingan pemanfaatannya dan tidak boleh dimiliki oleh siapapun. ${ }^{12}$ Dalam fikih

\footnotetext{
${ }^{11}$ Atho Mudzhar, "Membumikan Fikih ramah Lingkungan" dalam Mudhofar Abdillah, Al-Quran dan Konservasi Lingkungan (Jakarta: Dian Rakyat, 2010), xxx-xxxvi. Hal yang sama dikemukakan oleh A. Qadir Gassing. Menurutnya, fikih lingkungan perlu dikembangkan berdasarkan tiga pertimbangan; pertama, terjadinya krisis lingkungan dalam tiga dasawarsa terakhir, dan terus mengalami peningkatan. Jika krisis ini dibiarkan tanpa ada solusinya, niscya kehidupan di muka bumi ini akan mengalami kerusakan dan kehancuran, karena sumberdaya yang tersedia tidak mampu lagi mendukung keberlangsungan kehidupan, kedua, upaya pengendalian yang telah dilakukan pembentukan institusi yang khusus menangani masalah lingkungan serta regulasi melalui produk perundang-undangan tentang lingkungan hidup ternyata tidak mampu menahan laju degradasi lingkungan, ketiga, banyak ayat dan hadis yang berkaitan dengan lingkungan hidup tetapi belum dihimpun dan diorganisir untuk menghasilkan aturan-aturan moral, etika dan hukum yang bersifat syar'i untuk dijadikan panduan umat Muslim dan penduduk dunia dalam berperilaku terhadap lingkungannya. Lihat, A. Qadir Gasing, Fikih Lingkungan: Telaah Kritis tentang Penerapan Hukum taklifi dalam Pengelolaan Lingkungan Hidup, Pidato Pengukuhan Guru Besar UIN Alauddin di Makassar pada tanggal 8 Februari 2005, dikutip dari Hartini, Pelestarian Alam dan Lingkungan Perspektif Hukum Islam (Makassar: Alauddin University Press, 2012), 5.

${ }^{12}$ Ibn Qudâmah, al-Mughnî,Juz VIII (Mesir: Hijr, 1992), 170-171.
} 
Islam, konservasi ${ }^{13}$ ini disebut dengan harîm al-nahr. Lebih lanjut, Sulaimân bin Umar bin Muhammad al-Bujairimî menegaskan bahwa kawasan pinggiran sungai, demi kepentingan konservasinya, tidak boleh didirikan bangunan, sekalipun masjid; setiap bangunan di atasnya harus dibongkar. ${ }^{14}$

Selain harîm, dalam fikih klasik juga ditemukan konsep himâ. Hima adalah perlindungan suatu kawasan untuk menjaga habitat asli yang ada di dalamnya dan menjadikannya sebagai padang rumput bebas guna untuk menopang usaha peternakan. Pada masa Rasulullah kawasan naqi' dijadikan hima dan masa Umar ibn al-Khattab, wilayah syaraf dan rabazah juga dijadikan himâ. ${ }^{15}$ Ihyâ al-Mawât adalah prosedur pembukaan lahan mati, sedang iqthâ adalah pemberian lahan oleh penguasa kepada individu atau kelompok yang dipandang memiliki keahlian untuk mengelolanya. ${ }^{16}$

Bertolak pada konsep-konsep di atas, pengembangan fikih lingkungan dalam konteks fikih lingkungan keindonesiaan kontemporer berwujud menjadi: fikih sungai, fikih air, fikih pemukiman dan tata ruang, fikih pengelolaan sampah, fikih pengelolaan hutan dan tambang ${ }^{17}$, fikih ekologi industri, fikih ekologi wisata, fikih ekologi pelabuhan, fikih ekologi kelautan dan fikih ekologi lainnya. Konsep-konsep fikih tersebut dapat menjadi bahan pertimbangan dalam merumuskan kebijakan politik hukum lingkungan dan bertransformasi menjadi sebuah undangundang.

Fikih lingkungan kontemporer dibangun dengan pendekatan sosiologis dan pendekatan normatif sekaligus. Oleh karena itu, dalam

\footnotetext{
13 Konservasi adalah pengelolaan biospar bagi keperluan manusia, sehingga menghasilkan manfaat sebesar-besarnya bagi generasi kini dan menetapkan untuk memenuhi kebutuhan dan aspirasi generasi mendatang. Kegiatan konservasi merupakan kegiatan positif yang mencakup pengawetan, perlindungan dan pemanfaatan secara lestari, rehabilitasi dan peningkatan mutu lingkungan alam. Lihat, Hadi S. Alikodra, Konservasi Sumberdaya Alam dan Lingkungan (Bogor: Fakultas Kehutanan IPB, 2009), 21.

${ }^{14}$ Sulaimân ibn Umar ibn Muhammad al-Bujairimî, Hâsyiyah al-Bujairimî alâ Syarh Minhâj atThullâb, Juz III (Beirut: Dar al-Fikr, t.th), 190.

'bid., Lihat juga Ibn Qudamah, al-Mughni, Juz VIII (Kairo: Hijr, t.th), 97.

16 Terkait dengan konsep iqthâ ini, Muhammad al-Mâwardi dalam bukunya al-Ahkâm alSulthaniyah wa Wilâyat al-Dîniyyah menjelaskan iqthâ pada praktiknya terbagi dua macam: iqthâ al-tamlikk (menjadi hak milik) dan iqthâ al-istighlâl (hak guna pakai). Lebih lanjut, baca Al-Mâwardi, al-Ahkâm al-Sulthâniyyah wa al-Wilâyat al-Dîniyyah (Beirut: Dâr al-Fikr, t.th), 190.

${ }^{17}$ Konsep-konsep fikih di atas, telah dirumuskan oleh Sukarni dalam disertasinya yang kini telah diterbitkan dengan judul "Fikih Lingkungan Hidup". Lebih lanjut, baca Sukarni, Fikih Lingkungan Hidup, 155-185.
} 
pengembangannya harus memperhatikan prinsip-prinsip dasar etika yang terkandung dalam teks-teks keagamaaan, baik al-Qur'an maupun hadis. Prinsip-prinsip yang harus menjadi pertimbangan dan perhatian dalam pengelolaan sumber daya alam adalah sebagai berikut.

Pertama, prinsip kepemilikan mutlak. Semesta alam merupakan milik mutlak Allah sebagai pencipta, pengatur dan pengarah. Itu sebabnya, tata kelola lingkungan harus berbasis pemenuhan kewajiban dalam upaya menjaga dan mengelola lingkungan alam semesta dengan sesuai kehendak sang pemilik mutlak, Allah.

Kedua, prinsip pengelolaan dengan amanah. Alam diciptakan Tuhan untuk memenuhi kebutuhan manusia. Alam ditundukkan bagi manusia dengan sepenuhnya. Itu sebabnya, manusia sebagai pengelola lingkungan harus bertanggung jawab dan tidak boleh melampaui batas dalam mengeksploitasi sumber daya alam. Prinsip ini erat kaitannya dengan sisi kemaslahatan dan kemadaratan. Karena dalam Islam tidak mengajarkan antroposentrisme mutlak, tetapi antroposentrisme yang bertanggung jawab.

Ketiga, prinsip penggunaan secara hemat. Dalam upaya konservasi lingkungan, kekayaan alam semesta ini harus dimanfaatkan secara wajar. Prinsip ini akan memberikan arahan dan guidence dalam pemanfaatan sumber daya alam yang berimbang demi untuk pembangunan yang berkelanjutan.

Keempat, prinsip tanggung jawab dan resiko. Ajaran yang terkandung dala al-Quran mengajarkan bahwa segala kerusakan alam semesta disebabkan oleh kecerobohan dan tingkah laku desktruktif manusia. Itu sebabnya, dalam eksploitasi sumber daya alam harus memperhatikan dan mempertimbangkan dampak negatif yang ditimbulkan dalam setiap pemanfaatan sumber daya alam. Pertimbangan dampak ini dalam bahasa ushul fiqh disebut al-nazar ilâ al-ma'âl. ${ }^{18}$

Prinsip-prinsip di atas diharapkan melahirkan etika religius lingkungan yang mengajarkan keseimbangan relasi antara Tuhan, manusia dan alam sekitar. Etika ini melampaui asas keseimbangan dan kesatuan ekosistem yang hingga saat ini masih banyak digunakan oleh para ilmuwan dan praktisi lingkungan dalam merumuskan kebijakan pengelolaan lingkungan. Lebih lanjut, Sukarni menjelaskan bahwa konsep kesalehan lingkungan tersebut mengandung empat esensi

\footnotetext{
${ }^{18}$ Ibid., 198.
} 
penting. Pertama, penghargaan yang sangat tinggi terhadap alam. Kedua, penghormatan terhadap saling keterkaitan setiap komponen dan aspek kehidupan. Ketiga, pengakuan terhadap kesatuan penciptaan dan persaudaraan sesama makhluk. Keempat, menunjukkan bahwa etika harus menjadi alasan setiap perilaku dan penalaran manusia.

\section{Basis Epistemologi Fiqh al-Bî̀ah: Rekonstruksi Maqâshid al-Syarî’ah}

Fikih dan seperangkat metodologinya (ushûl al-fiqh) diasumsikan sebagai sumber bagi nilai dan perubahan. Dengan asumsi ini, fikih dan ushûl al-fiqh dipercaya berpotensi melakukan reformasi praktis dalam berbagai aspek kehidupan. Asumsi ini dipertegas oleh pernyataan Hallaq bahwa "dalam hukum Islam, otoritas senantiasa melibatkan kekuatan untuk menggerakkan proses continuity (kesinambungan) dan change (perubahan)". ${ }^{19}$ Secara historis, hukum Islam memang telah memprakarsai berbagai reformasi karena adanya berbagai tekanan kontekstual dan integritas keagamaan. Prinsip-prinsip hukum menyimpan kekuatan moral melalui konsep-konsep yang menjamin bahwa "perubahan hukum tidak hanya terjadi melalui satu cara yang khusus namun melekat dalam berbagai proses yang dibangun ke dalam struktur hukum". ${ }^{20}$

Dalam pengembangan fikih lingkungan harus didukung dengan sandaran metodologis yang mapan. Konstruksi fikih lingkungan dikonstruk dari penalaran dalil normatif berupa dalil-dalil al-Qur'an dan hadis serta kenyataan sosial dari perspektif sosiologis-empiris. Integrasi dua elemen ini akan melahirkan bangunan fikih yang lebih akomodatif dan komprehensif. Di satu sisi, ia tidak lari dari petunjuk teks di pihak lain tidak "menutup mata" terhadap fenomena yang terjadi di masyarakat.

Langkah utama yang menjadi garapan pengembangan fikih lingkungan adalah mencarikan format metodologis dalam merumuskan ijtihad fiqh al-bîah. Dari perangkat metodologis tersebut, nantinya dapat diproduk hukum-hukum yang bernuansa ekologis yang berdasarkan pada tuntutan realitas masyarakat modern. Hal ini dilakukan agar

\footnotetext{
${ }^{19}$ Wael B. Hallaq, Authority, Continuity and Change in Islamic Law,(Cambridge: Cambridge University Press, 2001), ix.

${ }^{20}$ lbid., 204.
} 
bangunan fikih lingkungan menjadi kokoh dengan ditopang metodologis yang akurat dan dapat dipertanggung jawabkan secara ilmiah.

Dalam ushul fikih, bahasan maqâshid al-syarîah adalah kajian yang menjadi 'primadona' di era kontemporer. Maqâshid al-syarîah menjadi pendekatan dalam merumuskan hukum oleh para cendikia Muslim kontemporer. Melalui pendekatan ini, muncul berbagai rumusan hukum terkait fikih realitas (fiqh al-wâqi'), fikih minoritas (fiqh al-aqalliyât) dan sebagainya. ${ }^{21}$ Secara substansial, maqâshid al-syarîah merupakan inti ajaran Islam dalam setiap perumusan hukum. Karena itu, fokus utama dalam maqâshid al-syarî̀ah adalah menciptakan hukum yang berorientasi pada kemaslahatan umat manusia (masâlih al-'ibâd). ${ }^{22}$

Pada prinsipnya, yang dimaksud dengan kemaslahatan adalah suatu usaha untuk mencapai manfaat dan mencegah mafsadat. Meraih manfaat merupakan tujuan kemaslahatan manusia dalam meraih tujuannya. Sementara yang dimaksud dengan maslahat menurut alGhazali adalah memelihara maqâshid al-syarîah itu sendiri. ${ }^{23}$ Maqâshid al-syarîah di sini maksudnya adalah menjaga al-mabâdi' al-khamsah atau yang juga dikenal dengan istilah al-kulliyât al-khamsah, atau aldharûriyât al-khamsah; menjaga agama, jiwa, akal, keturunan dan harta. Memelihara al-mabâdi' al-khamsah ini oleh al-Ghazâlî dikategorikan sebagai maslahah yang bersifat dharûrî, kullî dan qath'î. ${ }^{24}$

Para ushuliyyûn mengklasifikasikan maqâshid al-syarî̉ah menjadi tiga tingkatan, dharûriyyah, hâjiyyah dan tahsîniyyah. Yang pertama bersifat elementer untuk menjaga lima prinsip dasar hifz al-dîn (menjaga agama), hifz al-nafs (menjaga jiwa), hifz al-'aql (menjaga akal), hifz alnasl (menjaga keturunan), hifz al-mâl (menjaga harta), sedangkan yang

\footnotetext{
${ }^{21}$ Lihat Imam Mawardi, Fiqh Minoritas; Fiqh al-Aqalliyyât dan Evolusi Maqâshid al-Syarî'ah dari Konsep ke Pendekatan (Yogyakarta: LKiS, 2010).

${ }^{22}$ Urgensi posisi masalahat dalam kajian pembaruan pemikiran Islam juga diakui oleh Muhammad Khalid Masud. Ia mengatakan demikian:"The movement of modernism in Islam searched in Islamic tradition for a principle that whold help them grapple with the changing conditions. They found in maslaha such a concept. Naturally therefore more attention has been paid to the study of this concept in modern times than ever before" (Gerakan-gerakan pembaruan dalam Islam mencari dalam tradis Islam suatu prisip yang akan membentu mereka menghadapi kondisi-kondisi yang senantiasa berubah. Mereka menemukan konsep semacam itu di dalam maslahat. Makanya wajar saja jika pada zaman modern konsep ini mendapat perhatian lebih untuk dikaji dibandingkan sebelumnya). Lihat Muhammad Khalid Masud, Islamic Legal Philosophy, Edisi I (Islamabad: Research Institute, 1997), 173.

${ }^{23}$ Al-Ghazâlî, al-Mustashfâ min IIm al-Ushûl(Beirut: Dâr al-Fikr, t.th), 286.

${ }^{24}$ Ibid., 174, 253.
} 
kedua bersifat suplementer untuk menghilangkan kesulitan-kesulitan dalam hidup umat manusia. Sementara yang terakhir lebih bersifat komplementer, yang ketidaannya tidak menyebabkan kesulitan dalam hidup.

Hifz al-bî̀ah (menjaga lingkungan) oleh ushûliyyûn klasik tidak menjadi tujuan prioritas. Karena bisa jadi, mereka memahami menjaga lingkungan sudah include dalam pemeliharaan jiwa (hifz al-nafs). Sikap usuliyyûn klasik ini dapat diterima, karena kondisi lingkungan ketika dirumuskannya al-kulliyât al-khamsah -yang tidak memasukkan hifz albî̀ah di dalamnya, secara riil kondisi lingkungan belum mengalami krisis yang akut sebagaimana yang terjadi di era kontemporer. ${ }^{25}$

Rumusan al-kulliyât al-khamsah merupakan hasil ijtihad fuqahâ yang tidak bersifat statis. Konsep tersebut bisa berkembang sesuai dengan tuntutan dan perkembangan zaman dalam dinamika ijtihad fuqaha sebagai resposn terhadap fenomena-fenomena yang berkembang di masyarakat. Mislanya, di era al-Subkî, ia menambah hifz al-'ird (menjaga kehormatan) sebagai penambahan dari konsep kulliyât al-khams. Di era kontemporer, muncul ide tambahan hifz al-jamâ'ah atau hifz al-ummah yang digagas oleh Hamka Haq. Ali Yafie juga menggagas untuk memasukkan hifz al-bî̀ah sebagai rekonstruksi dari konsep kulliyyât alkhams itu sendiri. ${ }^{26}$ Sayangnya, gagasan Yafie belum dilengkapi dengan argumentatif yang mendudung gagasan tersebut.

Menurut penulis, konstruk argumentatif yang mendukung hifz albî̀a (menjaga lingkungan) sebagai bagian dari maslahat daru>riyyah adalah sebagai berikut: Pertama, fakta empiris bahwa persoalan lingkungan hidup dari pemanasan global dan efek rumah kaca, lubang ozon, hujan asam, deforestasi dan penggurunan hutan, banjir, kekeringan, tanah longsor, hingga punahnya keanekaragaman hayati sudah menjadi persoalan global saat ini. Seluruh bumi terancam. Tidak ada satu bangsa atau negara manapun yang luput dari dampak negatif krisis ini. Rusaknya alam membuat keseimbangan lingkungan hidup

\footnotetext{
${ }^{25}$ Dari sudut lingkungan hidup, pokok perhatian dewasa ini berkisar pada beberapa aspek yang dirasakan sebagai tekanan krisis yang membahayakan kelangsungan hidup manusia, seperti di antaranya ancaman terhadap kejernihan udara dan sumber air, terhadap bahaya zat-zat pangan (nutriens), terhadap produktifitas secara kontinyu dari kekayaan alam beserta fauna dan flora, dan sebagainya. Lihat KH. Ali Yafie, Menggagas Figh Sosial(Bandung: Mizan, 1995), 140.

${ }^{26}$ Lihat Hamka Haq, Aspek Teologis Konsep Maslahat dalam Kitab al-Muwafaqat. (Jakarta: Erlangga, 1997), KH. Ali Yafie, Merintis Figh Lingkungan Hidup (Jakarta: Yayasan Amanah, 2006).
} 
mengalami ketimpangan yang bukan lagi dipandang sebelah mata. Pemanasan global yang disertai perubahan iklim yang tidak menentu merupakan salah satu bukti bahwasanya bumi sedang mengalami krisis lingkungan. Rentetan bencana seperti banjir, tanah longsor, kebakaran dan penggundulan hutan, pencemaran dan lain sebagainya semakin menambahkan jajaran daftar memperparah kondisi bumi. Itu sebabnya, perlu perhatian serius terhadap gagasan hifz al-bî̀ah.

Kedua, konsep kulliyât al-khams dengan menjaga lima pilar: hifz al-dîn (menjaga agama), hifz al-nafs (menjaga jiwa), hifz al-aql (menjaga akal), hifz al-nasl (menjaga keturunan), hifz al-mâl (menjaga harta) tersebut hanya mengakomodir kemaslahatan terkait hubungan manusia dengan Tuhan dan hubungan manusia dengan manusia. Semanatara kemaslahatan dalam hubungan manusia dengan lingkungannya, alam semesta belum terakomodir secara proporsional. Dengan demikian, mempertahankan konsep kulliyât al-khams hanya berkutat pada hubungan manusia dengan Tuhan, dan hubungan manusia dengan sesama belum mampu mengeser paradigma umat Muslim terhadap interaksinya dengan lingkungan. Di sini perlu hifz al-bî̀ah dirumuskan ke dalam kulliyât al-khams demi mengakomodir kemaslahatan dalam hubungan manusia dengan lingkungannnya secara independen dan proporsional.

Ketiga, banyaknya dalil-dalil dari al-Qur'an yang melarang melakukan tindakan merusak alam dan perintah menjaga kelestarian alam serta menganjurkan untuk memanfaatkan sumber daya alam dengan sewajarnya. Perintah untuk memelihara lingkungan, dan sebaliknya, larangan merusak lingkungan ditemukan dengan jelas dalam ayat-ayat al-Qur'an dan hadits-hadits Nabi. Ancaman bagi perusak lingkungan (mufsidîn) berulang-ulang dinyatakan dalam al-Qur'an. ${ }^{27}$ Bahkan, sebagaimana dijelaskan, eksistensi alam sering digandengkan dengan ide tauhid, sehingga perintah atau larangan menjadi bermuatan sangat teologis. Selain itu, dalam hadis ditemukan perintah-perintah dan larangan-larangan terhadap hal-hal tertentu yang dimaksudkan sebagai perlindungan terhadap lingkungan, seperti menebang pohon secara sembarangan dan tanpa didasari oleh kepentingan yang jelas dan benar. $\mathrm{Hal}$ ini dimaksudkan sebagai pemeliharan kelestarian lingkungan, yang

\footnotetext{
${ }^{27}$ Lihat misalnya, QS. Al-Mâidah/5: 64, QS Hud: 85, QS al-A'râf: 86, QS. Al-Baqarah/2: 60, alQashas: 77, al-Baqarah/2: 12.
} 
termasuk di dalamnya pemeliharan keberlangsungan pemenuhan kebutuhan manusia.

Keempat, jika hifz al-bîah ditempatkan sejajar sebagai kebutuhan primer secara independen dalam maslahat dharûriyyât, maka tujuan pemeliharaan lingkungan menjadi tujuan prioritas (maqâshid alashliyyah), karena meskipun didasarkan atas dalil-dalil normatif dari alQur'an dan hadis, fiqh al-bî̀ah yang mengatur regulasi perlindungan lingkungan lebih merupakan human endeavor yang tergantung pada kreativitas ijtihad manusia, atau disebut dalam ushûl al-fiqh "dalam wilayah tradisi-tradisi" ('âdat). Sementara, patokan dalam tradisi adalah tujuan (al-ashl fî al-âdat al-iltifât ilâ al-ma'ânî). Dengan demikian, dalam konteks seperti ini, tujuan pemeliharaan lingkungan (hifz al-bî̀ah) adalah termasuk tujuan asasi.

Keempat, dalam hal persoalan al-maskût 'anhu (sesuatu yang tidak dijelaskan oleh teks, tetapi memiliki nilai kemaslahatan), tidak hanya karena banyaknya teks yang secara jelas menempatkan pemeliharaan lingkungan sebagai tujuan, tetapi juga ayat-ayat lain, meski di luar tema lingkungan, yang menegaskan pentingnya pemeliharaan lingkungan, seperti dibuktikan oleh al-Syâtibî ketika mendiskusikan tentang mubâh. Menurutnya, kebolehan tidak bersifat mutlak, karena makna yang tersimpan di balik ayat-ayat yang mencela kehidupan konsumerisme duniawi yang sia-sia (la'b dan lahw). Ini adalah "teks bisu" yang berkaitan dengan larangan eksploitasi alam yang berada di luar keperluan yang mendesak, tetapi didasarkan oleh keserakahan. Tujuan ini adalah maskût 'anhu.

Prinsip yang mendasari pertimbangan di atas adalah kemaslahatan manusia. ${ }^{28}$ Dalam mazhab Maliki, suatu masalah yang meski tidak ditetapkan oleh teks secara eksplisit, tetapi memiliki kemanfaatan adalah dianjurkan, bahkan wajib, atas dasar tujuannya yang tepat (al-muhdasât al-mahmûdah fî al-ma'nâ). Apalagi, jika pemeliharaan lingkungan (hifz al-bî̀ah) terkait dengan pelaksanaan kewajiban, maka memelihara lingkungan menjadi wajib, karena kaedah: "sesuatu yang bisa menentukan kesempurnaan pelaksanaan suatu kewajiban akan menjadi wajib pula" (mâ lâ yatimmu al-wâjib illâ bihi, fahuwa wâjib, dan "sarana

\footnotetext{
${ }^{28}$ Terkait kemaslahatan manusia di dunia, menurut Izz al-Dîn Abd. Al-Salâm bahwa manifestasi suatu kemaslahatan yang bersifat duniawi dapat dimungkinkan untuk diidentifikasi dalam realitas kehidupan melalui akal sehat.
} 
memiliki status hukum yang sama dengan perbuatan yang menjadi tujuan" (lil wasâil hukm al-maqâshid). ${ }^{29}$

Secara metodologis, fikih lingkungan dapat dikonstruksi melalui ijtihad deduktif-induktif dan integratif-holistik. Metode deduktif atau istinbâth al-ahkâm ${ }^{30}$ adalah sebuah metode berfikir fikih yang dimulai dari dalil (teks) dengan melalui analisis linguistik teks tersebut melahirkan hukum. Pada umumnya, metode deduksi adalah cara yang ditempuh ulama-ulama muhaddis dan mufassir karena salah satu tugas mereka adalah memberikan interpretasi (bayân) terhadap teks. Metode induktif (istiqrầî) biasanya dirumuskan oleh mujtahid yang berorientasi sosiologis-antropologis. Realitas sosial menjadi salah satu pertimbangan dalam menentukan rumusan hukum. ${ }^{32}$ Sementara pendekatan integratif-holistik adalah gabungan antara ijtihad istinbâthî

\footnotetext{
${ }^{29}$ Kedua kaedah di atas sangat tepat bila didasarkan pada asumsi pemeliharaan lingkungan hanya menjadi pelengkap ibadah, atau dari sudut pandangan fikih ibadah. Sebaliknya, jika pemeliharaan lingkungan dalam kapasitasnya sebagai isu krusial, maka status hukumnya bukan sebagai pelengkap, melainkan sebagai tujuan utama yang memiliki dasar-dasar teks, sebagaimana halnya juga ibadah.

${ }^{30}$ Term istinbâth al-ahkâm pada mulanya sebuah istilah netral yang dapat bermakna deduktif juga induktif, tetapi dalam praktiknya term tersebut terseret menuju pengertian deduktif saja. Lihat Ahmad Minhaji, "Reorientasi Kajian Ushul Figh", dalam M. Abdullah, dkk., Re-strukturisasi Metodologi Islamic Studies Mazhab Yogyakarta (Jogjakarta: SUKA Press, 2007), 124.

31 Terkait penalaranan istiqrâî ini, as-Syâtibî memiliki konsep yang unik. Menurutnya, istiqrấ ma'nawi menjadi salah satu metode penentuan hukum yang tingkat validitasnya tinggi sebagaimana dikemukakan dalam kitabnya "al-Muwâfaqât". Bagi as-Syâtibî, istiqrâ ma'nawî merupakan suatu metode penetapan hukum yang bukan hanya bertumpu pada satu dalil tertentu, tetapi dengan sejumlah dalil yang digabungkan antara satu dengan yang lain yang mengendung aspek dan tujuan yang berbeda, sehingga terbentuklah suatu perkara hukum berdasarkan dalil-dalil tersebut. Lebih lanjut, as-Syâtibî menyatakan bahwa para pemikir hukum Islam tidak boleh menetapkan tujuan as-Syâri' hanya berdasarkan dalil tertentu dan dengan cara tertentu saja, tetapi untuk menemukannya harus dilakukakan penelitian terhadap semua dalil yang relevan, baik sifatnya zâhir, mutlaq, muqayyad, kullliyah, atau juz'iyyah dalam berbagai variasi dalam setiap pembahasan fikih. Selain itu, harus mempertimbangkan qarâin al-ahwâl (indikasiindikasi keadaan signifikan), baik yang dinashkan (manqûlah) maupun yang tidak dinashkan (ghairu manqûlah). Dengan cara ini, kesimpulan hukum akan didapatkan secara pasti atau yakin. Lihat Duski Ibrahim, Metode Penetapan Hukum Islam; Membongkar Konsep Istiqrâ al-ma'nawî asSyâtibî̀(Yogyakarta: Ar-Ruzz Media, 2008), 162.

${ }^{32}$ Fikih sebagai hasil penafsiran para ahli fikih terhadap syariat memiliki nilai toleransi yang tinggi terhadap kebudayaan etnik yang bersifat kedaerahan. Bahkan, secara teoritis, niai toleransi tersebut teraktualisasi dalam kaidah fikih dengan suatu proposisi yang berbunyi al-âdat Muhakkamah. Lihat Badri Khaeruman, Hukum Islam dan Perubahan Sosial(Bandung: Pustaka Setia, 2010), 29.
} 
(deduktif) dan istiqrầî (induktif) sebagaimana yang telah dikembangkan oleh as-Syâtibî. ${ }^{33}$

\section{Nuansa Fikih Lingkungan dalam Hukum Nasional}

Lingkungan yang baik dan sehat merupakan hak asasi setiap manusia. Mengamini hal tersebut, UUD 1945 (amendemen kedua, tahun 2000) pasal $28 \mathrm{H}$ ayat (1) menyebutkan "Setiap orang berhak hidup sejahtera lahir dan batin, bertempat tinggal, dan mendapatkan lingkungan hidup yang baik dan sehat serta berhak memperoleh pelayanan kesehatan". Berdasarkan spirit itulah wawasan mengenai lingkungan hidup masuk dalam agenda besar pembangunan ekonomi nasional. Di sisi lain, ekosistem yang semakin menurun telah mengancam tidak saja kelangsungan perikehidupan manusia, namun juga makhluk hidup lainnya. Eskalasi pemanasan global semakin meningkat hingga berpotensi terhadap perubahan iklim yang pada gilirannya akan memperparah penurunan kualitas lingkungan. Menipisnya lapisan ozon, kerusakan mangrove, padang lamun, gambut, karst, dumping limbah, kegagalan mitigasi, instabilisasi mutu emisi dan udara ambien adalah ancaman serius yang perlu segera mendapatkan penyelesaian. Dalam konteks ini, perlu dilakukan perlindungan dan pengelolaan lingkungan secara terpadu dan konsisten.

Dalam rangka pemecahan persoalan lingkungan di atas, perlu adanya regulasi hukum untuk menjaga kelestarian lingkungan hidup. Oleh karena itu, pemerintah Indonesia, sejak 10 tahun setelah adanya konvensi Stockholm tahun 1972 yakni pada tahun 1982, menerbitkan UU No. 4 tahun 1982 tentang Pokok-Pokok Pengelolaan Lingkungan Hidup. ${ }^{34}$ Kelahiran Undang-Undang ini bukan terlambat karena sebelum dilahirkannya UU ini, perlindungan lingkungan hidup di Indonesia telah ada pada masing-masing lembaga departemen maupun

\footnotetext{
${ }_{33}$ Pendekatan integralistik dapat pula dimaknai sebagai gabungan, apa yang disebut dalam paradigma filsafat ilmu, antara normativisme positivisme/empirisme dan rasionalisme. Dalam masalah-masalah sosial empirik yang ta'aqquli (reasonable), ketiga pendekatan tersebut dapat berjalan secara simultan. Dalam kasus pengharaman minuman memabukkan, interpretasi deduktif teks (QS al-Mâidah: 90) dan qiyâs untuk menjangkau setiap minuman yang memabukkan, pertimbangan menghilangkan setiap yang memudaratkan dan mewujudkan kemaslahatan masyarakat secara empiris induktif, memperlihatkan bahwa normativisme-positivismerasionalisme dapat saling melengkapi dan berjalan bersama dalam penetapan suatu hukum (fikih). Lihat Abu Yasid, Aspek-aspek Penelitian Hukum (Yogyakarta: Pustaka Pelajar, 2010), 7-13.

34 Siswanto Sunarso, Hukum Pidana Lingkungan Hidup dan Strategi Penyelesaian Sengketa (Jakarta: Rineka Cipta, 2005), vi.
} 
non departemen yang sifatnya sektoral dan terkoordinasi. ${ }^{35}$ Bahkan jauh sebelumnya, secara substansial, UUD RI Tahun 1945 pasal 28H (1) ${ }^{36}$ dan pasal 33 (3 dan 4$)^{37}$ sudah mengatur perlindungan hukum dan hak mendapatkan lingkungan hidup yang baik dan sehat. ${ }^{38}$ Dengan demikian, UU tersebut pada dasarnya bertujuan untuk mengefektifkan dan efisiensi dalam perlindungan lingkungan hidup di Indonesia.

Pada tahun 1986, terbit Peraturan Pemerintah RI Nomor 29 Tahun 1986 tentang Analisis Mengenai Dampak Lingkungan (Amdal). Ketentuan tentang Amdal yang diatur berdasarkan PP Nomor 29 Tahun 1986, kemudian disempurnakan melalui PP Nomor 51 Tahun 1993 tentang Amdal. ${ }^{39}$

Sehubungan dengan menggaungnya demokratisasi dan perlindungan terhadap Hak Asasi Manusia (HAM), Pemerintah RI melahirkan UU Nomor 23 tahun 1997 tentang Pengelolaan lingkungan hidup. Substansi UU Nomor 23 Tahun 1997, lebih demokratis dan melindungi masyarakat terhadap korban pencemaran dan perusakan lingkungan hidup dengan adanya hak-hak antara lain, mendapatkan ganti kerugian, hak penyelesaian sengketa, baik melalui pengadilan maupun di luar pengadilan, hak untuk menggugat, baik yang dilakukan oleh masyarakat maupun kelompok masyarakat itu sendiri. ${ }^{40}$ Undangundang ini merupakan pengganti dari UU Nomor 4 Tahun 1982 tentang Ketentuan-Ketentuan Pokok Pengelolaan Lingkungan Hidup. Untuk mengoperasionalkan undang-undang tersebut, Pemerintah RI menerbitkan Peraturan Pemerintah Nomor 11 Tahun 1995 tentang Perubahan Atas Peraturan Pemerintah RI Nomor 19 Tahun 1994 tentang Pengelolaan Limbah Bahan Berbahaya dan Beracun. ${ }^{41}$

Kelahiran UU Nomor 23 tahun 1997 tentang Pengelolaan Lingkungan Hidup tersebut sebagian besar telah memberikan harapan

\footnotetext{
${ }^{35}$ Ibid., vi.

${ }^{36}$ Pasal 28H (1); Setiap orang berhak hidup sejahtera lahir dan batin, bertempat tinggal, dan medapatkan lingkungan hidup baik dan sehat serta berhak memperoleh pelayanan kesehatan.

37 Pasal 33 (3) : Bumi dan air dan kekayaan alam yang terkandung di dalamnya dikuasai oleh negara dan dipergunakan untuk sebesar-besar kemakmuran rakyat.. pasal 33 (4) : Perekonomian nasional diselenggarakan berdasar atas demokrasi ekonomi dengan prinsip kebersamaan, efisiensi berkeadilan, berkelanjutan, berwawasan lingkungan, kemandirian, serta dengan menjaga keseimbangan kemajuan dan kesatuan ekonomi nasional.

${ }^{38}$ Amandemen UUD 1945, lihat http://www.inoputro.com.

${ }^{39}$ Siswanto Sunarso, Hukum Pidana Lingkungan Hidup dan Strategi Penyelesaian Sengketa, 3.

${ }^{40}$ Ibid., vii.

${ }^{41}$ Ibid., 3 .
} 
baru terhadap perlindungan lingkungan hidup. Namun demikian, masih banyak menimbulkan persoalan-persoalan lingkungan yang belum terjawab hingga saat ini. Dengan karakteristik hukum lingkungan yang ada pada UU Nomor 23 Tahun 1997, dalam penegakannya bisa menggunakan instrument hukum administrasi Negara, hukum perdata, dan hukum perdata, dan hukum pidana, serta memberikan dampak seberapa jauh kemampuan undang-undang ini dapat menjamin keadilan dan kepastian hukum, yang tidak hanya melihat nilai manfaat undangundang ini belaka. ${ }^{42}$

Regulasi hukum melalui UU Nomor 23 tahun 1997 tentang Pengelolaan Lingkungan Hidup kemudian dikuatkan dengan UU RI No. 32 Tahun 2009 tentang perlindungan dan pengelolaan lingkungan hidup memberikan nuansa spirit fikih lingkungan yang kental. Dalam pasal 13 (1) dinyatakan: pengendalian pencemaran dan/atau kerusakan lingkungan hidup dilaksanakan dalam rangka pelestarian fungsi lingkungan hidup. (2) pengendalian pencemaran dan/atau kerusakan lingkungan sebagaimana dimaksud pada ayat (1) meliputi: pencegahan, penanggulangan, dan pemulihan. ${ }^{43}$

Dengan demikian, disadari atau tidak, negara melalui alat-alat konstitusinya telah mengimplementasikan konsep fiqh al-bîah sebagai instrumen penting dalam menyongsong kegiatan berbangsa dan bernegara. Dalam konteks ini, dibutuhkan supporting unit dari semua kalangan. Termasuk peran agama dalam menyikapi isu-isu lingkungan dari perspektif yang lebih praktis. Fiqh al-bîah tumbuh dengan kompleksitas problem ekologis secara multidisipliner.

Oleh karena itu, tesis Yusuf Qaradâwî tentang fikih ramah lingkungan yang menyatakan bahwa menjaga lingkungan (hifz al-bîah) sama dengan menjaga agama (dîn), jiwa (nafs), akal (aql), keturunan (nasl), dan harta (mâl). Rasionalitasnya adalah bahwa jika aspek-aspek agama, jiwa, akal, keturunan dan harta rusak, maka eksistensi manusia di dalam lingkungan menjadi ternoda. Dengan demikian, al-Qardâwî menjadikan hifz al-bîah sebagai kajian aksiologi ilmu-ilmu keislaman. ${ }^{44}$

\footnotetext{
42 Ibid.

43 Lihat Undang-Undang No 32 Tahun 2009 tentang Perlindungan dan Pengelolaan Lingkungan Hidup (PPLH).

${ }^{44}$ Lebih lanjut baca Yusuf al-Qaradâwî, Ri'âyah al-Bĩah Fî al-Syarîah al-Islâm (Kairo: Dâr al-Syuruq, 2006), 44-55.
} 
Melindungi dan mengelola lingkungan hidup tentu bukan persoalan yang mudah dan juga bukan hal yang sulit jika secara bersamasama berusaha dan bekerja keras karena tidak ada fenomena lingkungan yang bersifat unpredicable. Kendati apa yang dilakukan terhadap lingkungan tidak langsung dapat terasa manfaatnya. Sebuah adagium mengatakan bahwa cara paling cepat mencapai sebuah tujuan adalah dengan kerja keras dalam waktu yang relatif lama (asra'u al-tharîq li alghâyah thûl al-zamân fi al-jiddah). Setidaknya, aksi nyata yang dapat dilakukan saat ini adalah dengan tidak berbuat kerusakan terhadap lingkungan sekitar (ifsâd fî al-ardl), meskipun belum secara maksiamal bisa melindungi dan mengelolanya dengan baik (mâ lâ yudroku kulluh lâ yutraku kulluh).

\section{Eco-Literacy; Sebuah Keniscayaan}

Melek ekologi atau ecoliteracy adalah istilah yang digunakan oleh Capra untuk mengembarkan manusia yang sudah mencapai tingkat kesadaran tinggi tentang pentingnya lingkungan hidup. Istilah lain, yang juga semakna dengannya adalah ecological literacy. Capra menggunakan kedua istilah tersebut secara bergantian karena sesungguhnya ecoliteracy adalah singkatan darai ecological literacy itu sendiri. ${ }^{45}$

Ketika manusia sudah tercerahkan tentang pentingnya lingkungan hidup, maka ia akan terdorong untuk menjaga dan merawat bumi, ekosisitem, alam sebagai tempat tinggal dan berkembangnya kehidupan. Atas dasar inilah, manusia menata pola dan gaya hidupnya menjadi pola dan gaya hidup yang selaras dengan lingkungan hidup. Manusia menggunakan sikap "sadar lingkungan" ini, untuk menuntun hidupnya dalam segala dimensinya menjadi sebuah budaya yang merasuki kepada semua anggota manyasarakat dalam rangka menciptakan sebuah masyarakat yang berkelanjutan.

Reformasi pola dan gaya hidup yang ramah lingkungan harus melembaga dan menjadi sebuah budaya baru masyarakat modern, yakni

\footnotetext{
${ }^{45}$ Eco berasal dari bahasa Yunani, oikos artinya ruah tangga atau dalam pemahaman luas berarti alam semesta, bumi tempat tinggal semua kehidupan, habitat atau rumah tempat inggal semua kehidupan. Eco kemudian umum dipahami dan digunakan untuk kata lingkungan hidup. Ecology berarti ilmu tentang bagaimana merawat dan memelihara alam semesta tempat tingal makhluk hidup. Sementara literacy dalam bahasa inggris berarti melek huruf. Dalam pengertian luas, keadaan seseoarang sudah paham atau tahu tentang sesuatu. Lihat A. Sonny Keraf, Filsafat Lingkungan Hidup; Alam sebagai Sebuah Sistem Kehidupan (Yogyakarta: PT Kanisius, 2014), 127.
} 
budaya ramah lingkungan hidup. Dalam bahasa Capra sebagaimana dijelaskan oleh A. Sonny Keraf, terciptanya masyarakat berkelanjutan ini disebut dengan sustainable society.

Melek ekologis sebenarnya diinspirasi dan bersumber dari kearifan lokal. ${ }^{46}$ Berangkat dari nilai-nilai kearifan lokal tersebut diharapkan mampu memberi perhatian tinggi terhadap dampak negatif dari terjadinya krisis lingkungan yang semakian hari semakin parah. Dengan adanya kearifan lokal diharapkan mampu membendung arus paradigma antroposentrisme yang menjadi paradigma mainstream di kalangan masyarakat. Kearifan lokal juga diharapkan menggeser paradigma interaksi manusia terhadap lingkungannya menjadi paradigma ekosentrisme yang lebih ramah terhadap lingkungannya. Oleh karena itu, pelestarian lingkungan dengan memperhatikan kearifan lokal inilah yang mendorong eco-literacy, mendorong masyarakat sadar lingkungan akan terwujud dengan sebaik-baiknya.

\section{Simpulan}

Dari uraian di atas, dapat disimpulkan bahwa fikih lingkungan dalam Islam memiliki landasan normatif yang jelas dan embrionya dapat ditemukan dalam ijtihad ulama klasik terkait konsep ihyâ al-mawât, hima dan sebagainya. Konsep tersebut dapat dikembangkan sesuai dengan kebutuhan dan kemaslahatan manusia di setiap zamannya.

Basis epistemologi yang digunakan dalam penalaran fikih lingkungan yaitu gabungan penalatan bayani (normatif-deduktif) dan penalaran istislahi (empiris-induktif). Oleh karena itu, dalam rangka mendukung gagasan fiqh al-biah meniscayakan untuk merekonstruksi maqâshid syariah terkait kemaslahatan menjaga lingkunga menjadi tujuan prioritas (maqâshid al-ashliyyah) dan masuk ke dalam ranah kebutuhan primer (dharûrî) dalam kehidupan umat manusia.

Hukum nasional telah mengakomodir fikih lingkungan dengan memberikan perhatian terhadap pengelolaan lingkungan hidup yang tertuang dalam Undang-Undang Nomor 5 tahun 1990 tentang Konservasi Sumber Daya Alam Hayati dan Ekosistemnya, UU. No. 27 tahun 2007 yang telah diubah dengan UU No. 1 tahun 2014 tentang Pengelolaan Wilayah Pesisir dan Pulau-Pulau Kecil, UU No. 32 tahun 2009 tentang Perlindungan dan Pengelolaan Hidup dan sebagainya.

${ }^{46}$ Ibid., 128. 
Dengan demikian, secara umum gagasan pemeliharan lingkungan yang menjadi garapan fiqh al-bî̀ah sudah bertransformsi menjadi hukum nasional.

\section{Daftar Rujukan}

Abdillah, Mujiono. Fikih Lingkungan. Yogyakarta: Unit Penerbitan dan Percetakan YKPN, 2005.

Al-Bujairimî. Hâsyiyah al-Bujairimî alâ Syarh Minhâj al-Thullâb. Beirut: Dar al-Fikr, t.th.

Al-Ghazâlî. al- Mustashfâ min 'Ilm al-Ushûl. Beirut: Dâr al-Fikr, t.th. Alikodra, Hadi S. Konservasi Sumberdaya Alam dan Lingkungan. Bogor: Fakultas Kehutanan IPB, 2009.

Al-Mâwardi. al-Ahkâm al-Sulthâniyyah wa al-Wilâyat al-Dîniyyah. Beirut: Dâr al-Fikr, t.th.

Al-Qaradâwî, Yusuf. Ri'âyah al-Bî̀ah Fî al-Syarîah al-Islâm. Kairo: Dâr al-Syuruq, 2006.

Azizy, A. Qodri. Elektisisme Hukum Nasional: Kompetisi Antara Hukum Islam dan Hukum Umum. Yogyakarta: Gama Media, t.th.

Hallaq, Wael B. Authority, Continuity and Change in Islamic Law. Cambridge: Cambridge University Press, 2001.

Haq, Hamka. Aspek Teologis Konsep Maslahat dalam Kitab alMuwafaqat. Jakarta: Erlangga, 1997.

Hartini. Pelestarian Alam dan Lingkungan Perspektif Hukum Islam. Makassar: Alauddin University Press, 2012.

Ibrahim, Duski. Metode Penetapan Hukum Islam; Membongkar Konsep Istiqrâ al-ma'nawî al-Syâtibî. Jogyakarta: Ar-Ruzz Media, 2008.

Keraf, A. Sonny. Filsafat Lingkungan Hidup; Alam sebagai Sebuah Sistem Kehidupan. Yogyakarta: PT Kanisius, 2014.

Khaeruman, Badri. Hukum Islam dan Perubahan Sosial. Bandung: Pustaka Setia, 2010.

Khallâf, Abd Wahhâb. 'Ilm Ushûl al-Fiqh. Kuwait: Dâr al-Qalam, 1978. Mangunjaya, Fachruddin M. Bertahan di Bumi; Gaya Hidup Menghadapi Perubahan Iklim. Jakarta: yayasan Obor Indonesia, 2008. 
Masud, Muhammad Khalid. Islamic Legal Philosophy. Islamabad: Research Institute, 1997.

Mawardi, Imam. Fiqh Minoritas; Fiqh al-Aqalliyat dan Evolusi Maqâshid al-Syariah dari Konsep ke Pendekatan. Yogyakarta: LKiS, 2010.

Minhaji, Ahmad. "Reorientasi Kajian Ushul Fiqh", dalam M. Abdullah. dkk., Re-strukturisasi Metodologi Islamic Studies Mazhab. Yogyakarta. Jogjakarta: SUKA Press, 2007.

Mudzhar, Atho. "Membumikan Fikih ramah Lingkungan" dalam Mudhofar Abdillah. Al-Quran dan Konservasi Lingkungan. Jakarta: Dian Rakyat, 2010.

Qudamah, Ibn. al-Mugnî. Kairo: Hijr, t.th.

Sukarni. Fikih Lingkungan Hidup. Banjarmasin: Antasari Press, 2011.

Sunarso, Siswanto. Hukum Pidana Lingkungan Hidup dan Strategi Penyelesaian Sengketa. Jakarta: Rineka Cipta, 2005.

Susilo, Rachmad K. Dwi. Sosiologi Lingkungan dan Sumber Daya Alam;

Perspektif Teori \& Isu-Isu Mutakhir. Yogyakarta: Ar-Ruzz Media, 2012.

Syafi'i SJ., Ahmad. "Fiqih Lingkungan: Revitalisasi Ushul al-Fiqh untuk Konservasi dan Restorasi Kosmos". Paper disampaikan pada 9th Annual Conference of Islamic Studies, Surakarta 2-5 November 2009.

Tahopi, Ridwan. Konservasi Pesisir dalam Perspektif Studi Islam. Yogyakarta: Pustaka Pelajar, 2014.

Undang-Undang No 32 Tahun 2009 tentang Perlindungan dan Pengelolaan Lingkungan Hidup (PPLH)

Yafie, KH. Ali. Merintis Fiqh Lingkungan Hidup. Jakarta: Yayasan Amanah, 2006.

Yasid, Abu. Aspek-aspek Penelitian Hukum. Yogyakarta: Pustaka Pelajar, 2010. 